\title{
PENGARUH KONEKSI POLITIK TERHADAP KINERJA PERUSAHAAN
}

\section{(Studi Empiris pada Perusahaan Sektor Pertambangan yang terdaftar di BEI tahun 2014-2018) \\ Fajriatul' Azizah ${ }^{1}$ Muhammad Al Amin ${ }^{2}$}

\author{
${ }^{1,2}$ Fakultas Ekonomi dan Bisnis, Universitas Muhammadiyah Magelang \\ Corresponding Author: azizahfajriatul@gmail.com
}

\begin{abstract}
The company's financial condition can be described by the company's performance which is analyzed by various financial analysis measurement tools. The financial analysis is used to evaluate the company's financial condition as reflected by the company's performance in a period. The purpose of this study is to analyze the effect of political connections on company performance, especially in mining companies. Tobin's $q$ is used as an indicator to measure company performance. This research use data from annual report of mining sector companies listed on the Stock Exchange Indonesia in 2014-2018, which total 75 companies. Data collection method by purposive sampling method in order to get representative sample criteria Hypothesis testing uses multiple linear regression analysis. The results of the study that political connections do not affect the company's performance, as measured by the proportion of independent directors who have political connections.
\end{abstract}

Keywords : political connection, independent commisioner, Tobin's $Q$, company's performance

\begin{abstract}
Abstrak
Kondisi keuangan perusahaan dapat digambarkan melalui kinerja perusahaan yang dianalisis dengan berbagai alat ukur analisis keuangan. Analisis keuangan yang digunakan dapat menilai kondisi keuangan perusahaan yang tercermin dengan kinerja perusahaan suatu periode. Tujuan dari penelitian ini adalah untuk menganalisis pengaruh koneksi politik terhadap kinerja perusahaan, khususnya pada perusahaan pertambangan. Tobin's $q$ digunakan sebagai indikator untuk mengukur kinerja perusahaan. Penelitian yang dilakukan menggunakan data laporan tahunan (annual report) perusahaan sektor pertambangan yang terdaftar di Bursa Efek Indonesia tahun 2014-2018, yang berjumlah 75 perusahaan. Metode pengumpulan data yang digunakan yaitu metode purposive sampling agar dihasilkan kriteria sampel representatif sesuai kriteria. Pengujian hipotesis menggunakan analisis regresi linier berganda. Hasil penelitian bahwa koneksi politik tidak berpengaruh terhadap kinerja perusahaan, yang diukur dengan proporsi komisaris independen yang memiliki hubungan politik.
\end{abstract}

Kata kunci: koneksi politik, komisaris independen, Tobin's Q, kinerja pasar

\section{Article History \\ Received : 2020-02-05 \\ Revised : :2020-03-20 \\ Accepted : 2020-04-01

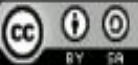

This is an open access article under the CC-BYSA License 


\section{Pendahuluan}

Persaingan usaha yang kompetitif sering terjadi dalam bisnis dengan tujuan memperbaiki kinerja perusahaan dan mengembangkan usaha tersebut agar tetap mampu berkembang dan bertahan kelangsungan usahanya. Semakin ketatnya tingkat kompetisi bisnis pada era globalisasi ini, seringkali memaksa perusahaan untuk meningkatkan kinerjanya menjadi lebih efektif dan efisien agar mampu bersaing dengan para kompetitornya. Kinerja perusahaan harus dioptimalkan secara efektif dan efisien dikarenakan kinerja merupakan tolok ukur keberhasilan perusahaan yang akan menjadi bagian awal yang dilihat oleh investor dan menjadi bahan pertimbangan dalam pengambilan keputusan (Anthony \& Govindrajan, 2005). Penilaian kinerja direfleksikan dalam bentuk tanggung jawab perusahaan dan kewajiban perusahaan dalam pelaporan kinerja serta pencapaian kinerja atas pemakaian sumber daya (Bourne, et al. 2003). Pencapaian kinerja tersebut tidaklah mudah, hal ini karena tujuan perusahaan sangatlah banyak dari aspek-aspek yang ada, termasuk aspek manajemen dalam perusahaan. Alat indikator dan variabel yang digunakan dalam penilaian kinerja juga sangat beragam.Namun, secara umum penilaian kinerja tercermin pada laporan keuangan yang meliputi informasi keuangan dan kinerja perusahaan (Purwati, et al.2003).

Faktor yang mempengaruhi keberhasilan perusahaan terdiri dari berbagai aspek. Diantara aspek-aspek yang ada salah satunya faktor lingkungan, baik lingkungan internal maupun eksternal, termasuk pengaruh lingkungan politik. Lingkungan politik seringkali digunakan oleh perusahaan dalam upaya memperbaiki kinerja perusahaan. Jalur politik digunakan oleh beberapa perusahaan dengan tujuan bisnis sebagai upaya untuk memperbaiki kinerja dan memaksimalkan laba. Jalur politik yang dimaksud salah satunya adalah koneksi politik pada perusahaan. Koneksi politik yang sering terjadi 
dalam perusahaan yaitu adanya petinggi negara atau pejabat negara dan anggota partai politik yang mempunyai koneksi atau merangkap jabatan sebagai pimpinan perusahaan atau pemegang saham tertinggi perusahaan (Faccio, 2006) .

Keterkaitan dan koneksi tersebut diharapkan memberikan manfaat dengan adanya sistem etika balas budi bagi kedua pihak, baik perusahaan maupun anggota politik.

Fenomena yang ada dalam perusahaan sektor pertambangan salah satunya yaitu Menteri Koordinator Bidang Kemaritiman, Luhut Binsar Pandjaitan, yang merupakan salah satu pemegang saham PT Toba Sejahtera, dan sejumlah anggota kerabat yang terhubung dalam koneks politik. Keterkaitan politik ini digunakan di area lokasi operasi perusahaan dalam memperoleh kekuasaan yang lebih besar terkait sumber daya alam yang dikelola. Izin usaha pertambangan mengalami kenaikan yang cukup signifikan dengan adanya koneksi politik.
Pertumbuhan perusahaan tersebut tidak terlepas dengan adanya koneksi politik, kebijakan pemberian izin usaha, serta hukum yang berlaku akan berpengaruh terhadap kinerja perusahaan dalam bidang batu bara ini (JATAM, 2019).

Kinerja perusahaan TOBA erat kaitannya dengan posisi jabatan Luhut dalam perusahaan yang ia kelola untuk menguntungkan perusahaannya. Kinerja perusahaan TOBA terlihat fluktuatif dari tahun 2011 hingga 2016. Laba TOBA pada tahun 2011 mencapai 58 juta dollar AS, dan pada tahun 2012 turun menjadi 3,2 juta dollar AS. Tahun 2013 dan 2014 terjadi pemulihan, namun di tahun 2015 dan 2016 terjadi penurunan lagi sebesar 31,80 persen dan 75,44 persen. Kondisi dalam periode ini koneksi politik digunakan oleh Luhut untuk mendorong perluasan usaha dalam upaya penggunaan batu bara yang ia gunakan untuk memperluas elektrifikasi di Indonesia, posisi ini digunakan dalam kepentingan TOBA di bisnis Pembangkit Listrik Tenaga 
Uap (PLTU) dengan hasil peningkatan cukup pesat (JATAM, 2019) . Berdasarkan fenomena tersebut perlu adanya penelitian terkait keterlibatan politik apakah akan lebih meningkatkan kinerja perusahaan atau sebaliknya menurunkan kinerja bagi perusahaan tersebut.

Kinerja suatu perusahaan digambarkan dalam kondisi keuangan perusahaan periode tertentu. Salah satu alat ukur yang digunakan dalam kinerja perusahaan adalah pengukuran kinerja keuangan. Kinerja keuangan adalah gambaran kondisi keuangan perusahan pada periode tertentu baik menyangkut aspek penghimpunan dana manapun penyaluran dana, yang biasanya diukur dalam indikator kecukupan modal, likuiditas, dan profitabilitas (Subramanyam \& Wild, 2010). Ketidak efeaktifan perusahaan dapat juga disebabkan oleh kinierja perusahaan, apakah kebijakan yang diterapkan sudah tepat dan bagaimana jalannya bisnis suatu perusahaan tersebut.
Hubungan timbal balik antara politis dan bisnis sering kali dilakukan dalam perusahaan. Konsekuensi yang diterima atas hubungan tersebut diantaranya hubungan politik digunakan dalam perumusan berbagai kebijakan yang dapat mendorong keberhasilan bisnis begitu pula dengan pelaku bisnis harus mampu dan bersedia membantu pendanaan dalam partai politik. Penelitian Faccio (2006) yang berjudul "Politically-connected firms " mengemukakan bahwa kriteria koneksi politik yaitu apabila salah satu pimpinan perusahaan, pemegang saham mayoritas atau kerabat dekat mereka yang pernak atau sedang menjabat sebagai anggota parlemen, pejabat tinggi negara, anggota parlemen dan atau pengurus partai besar di Indonesia.

Keuntungan yang dapat diperoleh sebuah perusahaan koneksi politik adalah perlakuan istimewa dari bank pengendali pemerintah, potensi kemudahan dalam membayarkan pajak yang lebih rendah, dan memenangkan monopoli pasar (Maaloul et al., 2016). 
Sedangkan menurut Wijantini (2007) keuntungan lain yang diperoleh perusahaan terkoneksi politik adalah akses mudah untuk mendapatkan kontrak usaha atau memenangkan tender proyek dari pemerintah. Penelitian menurut Kristanto (2019) dengan hasil koneksi politik berpengaruh negatif terhadap kinerja perusahaan, yang berarti semakin tinggi koneksi politik semakin menurunkan kinerja perusahaan. Koneksi politik memiliki potensi manfaat dan kerugian bagi perusahaan. Sejalan dengan penelitian yang dilakukan oleh Amdanata \& Mansor (2018) mengatakan bahwa koneksi politik berpengaruh secara negatif terhadap kinerja Bank Pemerintah Daerah.

Penelitian menurut Wang et al. (2018) bahwa koneksi politik dapat menguntungkan perusahaan. Bagaimanapun perusahaan memperoleh akses lebih untuk poyek investasi dan pinjaman jangka panjang. Pengelolaan perusahaan memperbaiki dan menurunkan asimetri informasi.
Konsisten dengan penelitian oleh Maaloul et al. (2016) yang dilakukan untuk menguji pengaruh koneksi politik terhadap kinerja dan nilai perusahaan, hasil penelitian ini membuktikan bahwa koneksi politik berpengaruh positif terhadap kinerja perusahaan. Semakin banyaknya minat investor yang beinvestasi saham pada perusahaan koneksi politik akan berimbas meningkatkat kinerja perusahaan dan memberikan berbagai manfaat bagi investor sendiri. Ketidakkonsistenan hasil penelitian mengenai koneksi politik dan fenomena yang terjadi pada perusaahaan pertambangan di Indonesia terkait praktik koneksi politik mendorong peneliti untuk menguji apakah koneksi politik akan mempengaruhi kinerja perusahaan.

\section{Tinjauan Pustaka}

\section{1 Teori Stakeholder}

Teori stakeholders pertama kali dikemukakan oleh Freeman (1984) dalam bukunya "Strategic management: $\quad$ A stakeholder 
approach”. Definisi stakeholders

menurut Freeman

mengatakan "any group or individual who can affect or is affected by the achievment of the organization's objectives". Kemudian dalam pendekatan teori tersebut berpendapat bahwa kelas-kelas pemangku kepentingan dapat diidentifikasi oleh posisinya atau dikaitkan memiliki satu, dua, atau ketiganya sebagai berikut: (1) kekuatan pemangku kepentingan untuk mempengaruhi perusahaan, (2) undang-undang hubungan antara pemangku kepentingan dengan perusahaan, dan (3) urgensi klaim pemangku kepentingan atas perusahaan.tersebut (Mitchell et al., 1997). Kurangnya perhatian terhadap para stakeholder akan berakibat pada pelaporan kinerja perusahaan berkaitan informasi sosial.

$$
\text { Mitchell et al. (1997) }
$$
mengatakan bahwa teori stakeholder merupakan bagian dari starategi manajemen yang bertujuan untuk meningkatkan hubungan dengan pihak luar perusahaan dan mengembangkan competitive advantage. Hubungan teori stakeholder dengan kinerja perusahaan yaitu dengan adanya teori stakeholder peningkatan kinerja perusahaan terjadi dengan adanya motivasi terhadap kegiatan operasi perusahaan dengan imbalan yang diperoleh sebanding atau lebih besar dari kontribusi yang diberikan kepada perusahaan.

\subsection{Pengaruh Koneksi Politik terhadap Kinerja Perusahaan}

Koneksi politik merupakan perusahaan yang masuk dalam kriteria petinggi negara atau pejabat negara dan anggota partai politik yang mempunayai koneksi atau merangkap jabatan sebagai pimpinan perusahaan atau pemegang saham tertinggi perusahaan (Faccio, 2006). Kinerja perusahaan digunakan sebagai alat ukur prestasi perusahaan dalam meningkatkan profitabilitas perusahaan (Kristanto, 2019). Pengukuran kinerja yang digunakan penelitian ini yaitu rasio Tobin's $q$ yang dihitung dari perbandingan market value of share ditambah 
hutang dengan total asset. Penelitian oleh Kristanto (2019), Wulandari (2018), dan Amdanata dan Mansor (2018) mengatakan bahwa political connections berpengaruh secara negatif terhadap kinerja. Sedangkan beberapa penelitian terdahulu (Wang et al., 2018; Maaloul et al., 2016) membuktikan bahwa terdapat pengaruh positif antara koneksi politik dengan kinerja perusahaan dan nilai perusahaan. Hipotesis yang dapat dirumuskan atas dasar penjelasan tersebut adalah :

$\mathrm{H}_{1}$. Koneksi politik berpengaruh terhadap kinerja perusahaan

\section{Metode Penelitian}

Penelitian ini menggunakan populasi perusahaan sektor pertambangan di Indonesia yang terdaftar di Bursa Efek Indonesia yang terlibat dalam koneksi politik pada tahun 2014-2018. Pemilihan sampel perusahaan dipilih dengan metode purposive sampling. Kriteria sampelnya sebagai berikut: a. Perusahaan sektor pertambangan yang terdaftar di Bursa Efek Indonesia (BEI) tahun 2014-2018, perusahaan pertambangan dipilih dalam penelitian ini karena terdapat beberapa perusahaan pertambangan di Indonesia memiliki koneksi politik

b. Laporan tahunan (annaual report) atau laporan keuangan (financial report) yang diterbitkan perusahaan secara berturut-turut dari tahun 2014-2018

c. Terdapat hubungan politik pada board of director atau independent of director

Jenis data sekunder dalam laporan keuangan dan laporan tahunan perusahaan sektor pertambangan yang telah diaudit pada tahun 2014-2018 yang terdatar di BEI. Variabel yang digunakan dan pengukuran variabel yang digunakan adalah sebagai berikut :

1. Kinerja Perusahaan

\begin{tabular}{llr}
\multicolumn{2}{c}{ Kinerja } & perusahaan \\
digunakan & untuk mengukur \\
kemampuan & perusahaan untuk
\end{tabular}


merpertahankan kelangsungan usaha (Kristanto, 2019). Alat ukur yang digunakan untuk mengukur kinerja perushaan Tobin's q ratio dinilai mampu mencerminkan keadaan perusahaan ditinjau dari harga saham dan proporsi saham yang beredar (Tobin \& Brainard, 1968). Tobin's $q$ merupakan suatu rasio yang dipilih dalam menilai rasio pasar saham, yang menunjukkan potensi perkembangan investasi. Formulasi TOBINS : (MVS + D) / TA

MVS : Nilai pasar saham yang beredar. D : Debt

TA : Total aset.

Tobin's $q$ yang digunakan oleh (Weston \& Copeland, 2001) adalah sebagai berikut: :

\section{Koneksi Politik}

Koneksi politik adalah jika dalam suatu perusahaan, petinggi negara atau pejabat negara dan anggota partai politik yang mempunayai koneksi atau merangkap jabatan sebagai pimpinan perusahaan atau pemegang saham tertinggi perusahaan (Faccio, 2006). Koneksi politik dalam penelitian ini dilihat dari komisaris independen yang memiliki hubungan politik yaitu anggota pejabat kenegaraan, purnawirawan TNI/POLRI, menteri negara atau mantan menteri negara, anggota dan mantan dari partai politik serta mantan atau anggota Dewan Perwakilan Rakyat (DPR) yang merangkap jabatan sebagai komisaris independen perusahaan (Faccio, 2006). Proporsi komisaris independen memiliki hubungan politik (Yusoff et al., 2015) yaitu Persentase dari perbandingan komisaris independen yang memiliki hubungan politik dengan total Jumlah komisaris

3. Variabel Kontrol

a. Ukuran Perusahaan

Ukuran perusahaan merupakan skala yang digunakan untuk mengukur besar kecilnya perusahaan. Cara untuk mengukur besar kecilnya perusahaan diantaranya: total 
aktiva, long size, nilai pasar saham dan lain-lain (Brigham \& Houston, 2013). Penelitian ini mengukur perusahaan dengan total asset yang diubah dalam bentuk logaritma (Kristanto, 2019). Dalam penelitian sebelumnya, ukuran perusahaan berhubungan positif terhadap hubungan politik. Semakin besar ukuran suatu perusahaan maka semakin tinggi adanya hubungan terhadap politik. Ukuran perusahaan dirumuskan sebagai berikut (Sawir, 2004):

$$
\text { Size }=\log (\text { Total Aset })
$$

b. Jenis Perusahaan

Perusahaan di Indonesia digolongkan menjadi bermacammacam jenis. Secara garis besar jenis dan kepemilikan perusahaan dikelompokkan menjadi dua, yaitu perusahaan milik negara dan perusahaan milik pihak swasta (Musselman \& Jackson, 1992). Dengan demikian tingkat koneksi politik antara perusahaan BUMN dan swasta akan berbeda. Penelitian ini mengukur perusahaan BUMN dengan pengukuran variabel dummy dengen nilai 1 dan non BUMN dengan nilai 0 (Kristanto, 2019).

\section{Hasil dan Pembahasan}

\subsection{Statistik Deskriptif}

Tabel 1 menunjukkan hasil bahwa rata-rata indeks kinerja pasar (Tobins) 112.7733\%, nilai minimum 15.00, dan nilai maksimum 790.00. Kondisi ini menunjukkan bahwa tingkat kinerja pasar dengan proksi kinerja pasar oleh sampel perusahaan sangat baik. Variabel koneksi politik memiliki rata-rata $28.6933 \%$, nilai minimum 0.00 dan maksimal 100. N. Ukuran perusahaan memiliki nilai ratarata 0,1333 , nilai maksimal 1 dan nilai minimal 0. Variabel jenis perusahaan memiliki nilai rata-rata $9.0709 \%$, nilai maksimum 9.94 dan minimum 8.07. Kondisi ini menunjukkan kondisi perusahaan yang cukup baik, mendekati nilai rata-rata. 
Tabel 1

Uji Statistik Diskriptif

\begin{tabular}{lrrrrr}
\hline & $\mathrm{N}$ & \multicolumn{1}{c}{ Min } & \multicolumn{1}{c}{ Max } & \multicolumn{1}{c}{ Mean } & \multicolumn{1}{c}{ Std. Deviation } \\
\hline KP & 75 & -15.00 & 790.00 & 106.2000 & 104.66045 \\
PC & 75 & 10.00 & 100.00 & 31.4933 & 14.84731 \\
UK & 75 & 8.07 & 9.94 & 9.0709 & .53368 \\
JP & 75 & .00 & 1.00 & .1333 & .34222 \\
Valid N (listwise) & 75 & & & & \\
\hline \multicolumn{2}{l}{ Sumber: Data diolah dengan program SPSS 25 }
\end{tabular}

Sumber: Data diolah dengan program SPSS 25

\subsection{Uji Asumsi Klasik}

\subsubsection{Uji Normalitas}

Tabel 2 menunjukkan hasil uji normalitas dengan penngujian non parametrik Kolmogorov-Smirnov (K-S) menunjukkan nilai sebesar $0.490>0.005$, maka dapat disimpulkan bahwa model regresi terdistribusi secara normal.

Tabel 2

Uji Normalitas

One-Sample Kolmogrov-Smirnov Test

\begin{tabular}{lr}
\hline & Unstandardized Residual \\
\hline Kolmogorov-Smirnov Z & .834 \\
Asymp. Sig. (2-tailed) & .490 \\
\hline
\end{tabular}

Sumber: Data diolah dengan program SPSS 25

\subsubsection{Uji Multikolinieritas}

Tabel 3 menunjukkan hasil uji multikolinearitas dengan variabel dependen kinerja pasar (TOBINS) menunjukkan bahwa variabel koneksi politik (PC), ukuran perusahaan (UK), dan jenis perusahaan (JP) dengan hassil nilai toleran lebih dari 0.1 dan nilai VIF tidak melebihi 10, sehingga dapat disimpulkan bahwa dalam model regresi tidak terjadi multikolinearitas.

Tabel 3

Uji Multikolinieritas

Sumber: Data diolah dengan program SPSS 25

\begin{tabular}{lrrl}
\hline Variabel & Tolerance & \multicolumn{1}{c}{ VIF } & \multicolumn{1}{c}{ Keterangan } \\
\hline PC & .892 & 1.121 & Tidak terdapat multikolinearias \\
UK & .891 & 1.122 & Tidak terdapat multikolinearias \\
JP & .999 & 1.001 & Tidak terdapat multikolinearias \\
\hline
\end{tabular}




\subsubsection{Uji Heteroskedastisitas}

Uji heteroskedastisitas pada penelitian ini dilakukan dengan menggunakan uji Glejser. Tabel 4 menunjukkan hasil uji
Hasil tingkat signifikan lebih tingi dari 0,005 ( $>>0.005), \quad$ sehingga hasil tersebut dapat disimpulkan dalam model regresi tidak terdapat heteroskedastisitas.

heteroskedastisitas dengan uji Glejser.

\section{Tabel 4}

Uji Heteroskedastisitas

\begin{tabular}{ccc}
\hline Variabel & Signifikansi & Keterangan \\
\hline PC & .952 & Tidak terdapat heteroskedastisitas \\
UK & .685 & Tidak terdapat heteroskedastisitas \\
JP & .633 & Tidak terdapat heteroskedastisitas \\
\hline
\end{tabular}

Sumber : Data diolah dengan program SPSS 25

\subsubsection{Uji Autokorelasi}

Uji autokorelasi dalam penelitian ini dilakukan dengan menggunakan uji Durbin-Watson (DW test). Berdasarkan jumlah $\mathrm{n}$ sebanyak 75 dan $\mathrm{k}=3$. Lampiran tabel 3 menunjukkan nilai Durbin Watson 2.173 tabel batas bawah (dl) 1,543 dan nilai Durbin Watson batas atas (du) 1,709. Hasil uji autokorelasi diperoleh nilai DW hitung 2.173, diatas nilai (du) 1,709 dan 4-du sebesar 2.291 lebih besar dari durbin watson maka model regresi tersebut menunjukkan bahwa tidak terjadi autokorelasi.

Tabel 5

Uji Autokorelasi

\begin{tabular}{rlrrrr}
\hline Model & R & R Square & $\begin{array}{c}\text { Adjusted R } \\
\text { Square }\end{array}$ & $\begin{array}{l}\text { Std. Error of } \\
\text { the Estimate }\end{array}$ & $\begin{array}{c}\text { Durbin- } \\
\text { Watson }\end{array}$ \\
\hline 1 & $.305^{\mathrm{a}}$ & .093 & .053 & .28557 & 2.173 \\
\hline
\end{tabular}

Sumber : Data diolah dengan program SPSS 25

\subsection{Analisis Regresi Berganda}

Tabel 6 menunjukkan hasil koefisien regresi, diperoleh persamaan regresi dalam analisis regresi linier berganda sebagai berikut:

$$
\begin{aligned}
K P= & 0.405+9.38 \text { PC }-0.021 \mathrm{UK}- \\
& 0.038 \mathrm{JP}+\mathrm{e}
\end{aligned}
$$


Tabel 6

Hasil Uji Regresi Linier Berganda

\begin{tabular}{|c|c|c|c|c|c|c|}
\hline \multirow[t]{2}{*}{ Model } & \multirow[b]{3}{*}{ (Constant) } & \multicolumn{2}{|c|}{ Unstandardized Coefficients } & \multirow{2}{*}{$\begin{array}{c}\begin{array}{c}\text { Standardized } \\
\text { Coefficients }\end{array} \\
\text { Beta }\end{array}$} & \multirow[t]{2}{*}{$\mathrm{T}$} & \multirow[t]{2}{*}{ Sig. } \\
\hline & & $\mathrm{B}$ & Std. Error & & & \\
\hline \multirow{4}{*}{1} & & .405 & 468 & & .865 & .390 \\
\hline & LOGUK & -.021 & .052 & -.051 & -.407 & .685 \\
\hline & JP & -.038 & . 080 & -.060 & -.479 & .633 \\
\hline & $\mathrm{PC}$ & $9.387 \mathrm{E}-005$ & .002 & .007 & .060 & .952 \\
\hline
\end{tabular}

Sumber : Data diolah dengan program SPSS 25

\subsection{Uji Koefisien Determinasi}

Tabel 7 menunjukkan hasil koefisien determinan, besarnya nilai adjusted R square sebesar 0,093 (9,3\%). Hasil tersebut menunjukkan bahwa presentase pengaruh variabel independen koneksi politik terhadap kinerja pasar perusahaan dapat dijelaskan oleh variabel koneksi politik sebesar $9,3 \%$ sedangkan sisanya $90,7 \%$ dijelaskan oleh variabel lain.

Tabel 7

Uji Koefisien Determinasi

\begin{tabular}{ccccc}
\hline Model & $\mathrm{R}$ & R Square & Adjusted R Square & Std. Error of the Estimate \\
\hline 1 & $.361^{\mathrm{a}}$ & .130 & .093 & .31190 \\
\hline
\end{tabular}

Sumber: Data diolah dengan program SPSS 25

\subsection{Uji Statistik F}

Tabel 8 menunjukkan hasil uji statistik F, model regresi penelitian ini diperoleh F hitung sebesar 3,488 dengan tingkat probabilitas sebesar $0,020(<0,05)$. Pada df1 $=3$ dan df2 $=$
70 nilai $F$ tabel 2.74. Hasil $F$ hitung (3.488) > F tabel (2.74) menunjukkan bahwa $\mathrm{Ha}$ diterima dan $\mathrm{H}_{0}$ tidak diterima, sehingga model regresi penelitian telah fit.

\section{Tabel 8}

Uji Statistik F

\begin{tabular}{lrrrrr}
\hline Model & Sum of Squares & Df & Mean Square & F & Sig. \\
\hline Regression & 1.018 & 3 & .339 & 3.488 & $.020^{\text {b }}$ \\
Residual & 6.810 & 70 & .097 & & \\
Total & 7.828 & 73 & & & \\
\hline
\end{tabular}

Sumber : Data diolah dengan program SPSS 25 


\subsection{Uji t}

Tabel 9 menunjukkan hasil uji $\mathrm{t}$, diketahui nilai $\mathrm{t}$ hitung -0.987 lebih kecil dari t tabel $1.9930 \quad(-0.987<$ 1,9930) dengan tingkat signifikans 0,322. Hasil ini menunjukkan bahwa nilai t hitung berada pada daerah Ho diterima, jadi variabel koneksi politik tidak berpengaruh terhadap tidak berpengaruh terhadap kinerja pasar perusahaan artinya hipotesis $1\left(\mathrm{H}_{1}\right)$ tidak diterima

Tabel 9

Hasil Uji t

\begin{tabular}{ccccc}
\hline Variabel & $\mathrm{t}$ hitung & $\mathrm{t}$ tabel & Sig. & Keterangan \\
\hline $\mathrm{PC}$ & -.987 & 1.9930 & .327 & $\mathrm{H}_{1}$ ditolak \\
\hline
\end{tabular}

Sumber : Data diolah dengan program SPSS 25

\subsection{Pembahasan}

Hasil penelilian ini menunjukkan bahwa koneksi politik tidak berpengaruh terhadap kinerja perusahaan. Penelitian ini tidak menerima hipotesis satu $\left(\mathrm{H}_{1}\right)$ yang menyatakan bahwa koneksi politik berpengaruh terhadap kinerja perusahaan. Konsisten dengan hasil penelitian Kristanto (2019) bahwa koneksi politik tidak berpengaruh terhadap kinerja perusahaan adanya koneksi politik pada perusahaan pertambangan tidak akan mempengaruhi baik atau buruknya kinerja perusahaan. Sedangkan penelitian lain oleh Osazuwa et al. (2016) yaitu terdapat pengaruh secara negatif antara koneksi politik dengan kinerja perusahaan yang berimplikasi pada auditor, pemegang saham, dan manajemen. Perusahaan yang termasuk dalam koneksi politik, mengeluarkan biaya yang banyak untuk pendanaan dan biaya perijinan untuk kemudahan dan kelancaran dalam kontrak atau untuk memenangkan tender proyek pemerintahan sehingga dampaknya menurunkan profitabilitas dan kinerja perusahaan .

Koneksi politik pada perusahaan pertambangan sebagian besar 
digunakan sebagai upaya untuk memperluas industri tekait dengan ijin usaha pertambangan. Namun, disisi lain ijin usaha yang diberikan tidak terlepas dari biaya yang besar untuk mendapatkn kemudahan dalam pemberian ijin. Selain itu ketatnya aturan dari pemerintah terkait dengan anggota politik dan anggota pejabat pemerintahan tidak boleh merangkap secara langsung sebagai dewan direksi atau komisaris perusahaan menjadian bukti empiris bahwa koneksi politik mempengaruhi kinerja perusahaan. Hal ini menjadikan keberadaan koneksi politik tidak digunakan sepenuhnya untuk memenuhi kebutuhan perusahaan. Biaya yang besar untuk memperoleh kemudahan dan kelancaran dalam kontrak atau untuk memenangkan tender proyek pemerintahan sehingga dampaknya mengurangi hasil akhir dari keuntungan yang diperoleh.

Penelitian ini tidak didukung oleh teori stakeholder oleh Freeman (1984). Koneksi politik yang diproksikan dengan komisaris independen yang memiliki hubungan politik tidak mempengaruhi keputusan investor sebagai stakeholder untuk melakukan investasi dalam perusahaan. Hal ini terjadi karena koneksi politik menyebabkan fungsi controling dan monitoring tidak bisa berjalan secara optimal (Agrawal \& Knoeber, 2001). Pengaruhnya akan berimbas pada investor, salah satunya yaitu pemegang saham minoritas, dan ketidaktransparansi manajemen yang menyebabkan pencapaian kinerja oprasional tidak maksimal, sehingga investor kurang tertarik berinvestasi pada perusahaan.

Hasil penelitian tidak konsisten dengan penelitian Wang et al. (2018) bahwa koneksi politik dapat menguntungkan perusahaan. Bagaimanapun perusahaan memperoleh akses lebih untuk proyek investasi dan pinjaman jangka panjang. Pengelolaan perusahaan mampu memperbaiki dan menurunkan asimetri informasi. Begitu pula Penelitian oleh Maaloul et al. (2016) membuktikan bahwa terdapat pengaruh positif antara 
koneksi politik dengan kinerja dan nilai perusahaan. Hasil tersebut dibukikan dengan peningkatan minta investor dalam penanaman modal dan berinvestasi di perusahaan yang terkoneksi politik sehingga meningkatkan dan menambah manfaat bagi perusahaan.

\section{Kesimpulan}

Hasil pengujian adjusted $R$ square sebesar 0,093 (9,3\%). Hasil penelitian menyimpulkan bahwa presentase pengaruh variabel independen koneksi politik terhadap kinerja pasar perusahaan dapat dijelaskan oleh variabel koneksi politik sebesar $9,3 \%$ sedangkan sisanya 90,7\% dijelaskan oleh variabel lain yang tidak diteliti (Ghozali, 2018). Berdasarkan hasil uji t, dapat disimpulkan bahwa $\mathrm{H}_{1}$ tidak diterima, artinya tidak ada pengaruh koneksi politik terhadap kinerja perusahaan.

Penelitian ini memiliki keterbatasan antara lain penelitian ini belum dapat mengungkapkan secara keseluruhan faktor-faktor yang dapat mempengaruhi kinerja perusahaan seperti pengungkapan CSR (Tangke, 2019), kepemilikan asing (Osazuwa et al, 2016), kepemilikan keluarga, kepemilikan institusional, dan struktur modal. Keterbatasan lain dalam penelitian ini yaitu sampel perusahaan hanya perusahaan sektor pertambangan di Bursa Efek Indonesia sebagai objek penelitian.

Penelitian selanjutnya diharapkan menambah proksi pengukuran koneksi politik dari proksi lainnya, misalnya membedakan antara tahun sebelum dan sesudah adanya suatu peristiwa politik. Sektor perusahaan yang dijadikan sampel sebaiknya tidak hanya sektor pertambangan, namun bisa diperluas lagi dalam sektor lain, misalnya sektor keuangan, non keuangan, manufaktur dan perusahaan jasa.

\section{DAFTAR PUSTAKA}

Agrawal, A., \& Knoeber, C. R. (2001). Do Some Outside Directors Play A. Journal of Law And Economics, 179-198.

Amdanata, D. D., \& Mansor, N. (2018). Do Political Connections Affect The Prformance Of Indonesian 
Regional Development Banks. International Journal Of Accounting And Bussiness, 109-118.

Anita, Kirmizi, \& Savitri , E. (2016). Pengaruh Family Ownership Terhadap Kinerja Keuangan: Strategi Bisnis Dan Agency Cost Sebagai Variabel Moderating . Jurnal Akuntansi, 1-15.

Anthony, R. N., \& Govindrajan, V. (2005). Mangement Control System. Jakarta : Salemba Empat.

Brigham, E., \& Houston, J. (2013). Dasar-Dasar Manajemen Keuangan. Jakarta: Salemba Empat.

Bourne, M., Neely, A., Mills, J., \& Platts, K. (2003). Implementing Performance Measurement Systems: A Literature Review. Int. J. Business Performance Management, 1-24.

Faccio, M. (2006). PoliticallyConnected Firms. The American Economic Review, 369-386.

Freeman, R. (1984). Strategic Management: A Stakeholder Approach. . Boston: Pitman.

Ghozali, I. (2018). Aplikasi Analisis Multivariate Dengan Program Ibm Spss 25 Edisi 9. Semarang: Badan Penerbit Universitas Diponegoro.

JATAM. (2019). Coalruption Elite Politik Dalam Pusaran Bisnis Batu Bara. Retrieved from www.jatam.org pada tanggal 13 Maret 2019.
Kristanto, A. T. (2019). Pengaruh Political Connections Terhadap Kinerja Perusahaan. Exero Journal Of Research In Business And Economic, 1-21.

Maaloul, A., Chakroun, R., \& Yahyaoui , S. (2016). The Effect Of Political Connections On Companies' Performance And Value : Evidance From Tunisian Companies After The Revolution. Journal Of Accounting In Emerging Economies, 1-38.

Mitchell, R. K., Agle, B. R., \& Wood, D. J. (1997). Toward A Theory Of Stakeholder Identification And Salience: Defining The Principle Of Who And What Really Counts . Academy Of Management Review, 853-886.

Musselman, V. A., \& Jackson, J. H. (1992). Introduction To Modern Business. New Jersey: Prentice Hall.

Osazuwa, N. P., Che-Ahmad, A., \& Che-Adam, N. (2016). Political Connection, Board Characteristics And Firm Performance In Nigeria. The European Proceedings Of Social \& Behavioral Sciences, 769-774.

Sawir, A. (2004). Analisis Kinerja Keuangan Dan Perencanaan Keuangan. Jakarta: Pt. Gramedia Pustaka Utama.

Su, Z.-Q., \& Fung, H.-G. (2013). Political Connections And Firm Performance In $\mathrm{C}$ Hinese Companies. Pacific Economic Review, 283-317. 
Subramanyam, K., \& Wild, J. J. (2010). Analisis Laporan Keuangan Edisi 10. Jakarta: Salemba Empat.

Tangke, P. (2019). Pengaruh Political Cconnections Dan Foreign Ownership Terhadap Nilai Perusahaan Melalui Corporate Social Responsibility. Jurnal Akuntansi \& Keuangan Daerah, $1-15$.

Wang, Y., Yao, C., \& Kang, D. (2018). Political Connection And Firm Performance : Evidence For Government Official Site Visit. Pasific-Basin Finance Journal, 1-16.

Weston, J. F., \& Copeland, T. E. (2001). Manajemen Keuangan (9th ed.). Jakarta : Binarupa Aksara.

Wijantini. (2007). A Test Of The Relationship Between Political Connection And Indirect Costs Of Financial Distress In Indonesia. Asian Academy of Management Journal Of Accounting And Finance, 6181.

Wulandari, L. (2018). Pengaruh Political Connection Pada Dewan Komisaris Dan Dewan Direksi Terhadap Kinerja Perusahaan Sektor Pertambangan Yang Terdaftar Bei . Jurnal Ilmiah Mahasiswa Universitas Surabaya , 11961226.

Yusoff, W., Salleh,, M., Ahmad, A., \& Idris, F. (2015). Estimating The Value Of Political Connection To Malaysia's Richest .
Journal Of Developing Areas, Vol. 49, No. 5 